\title{
Faculty Engagement in Online Education: Applying the Perceived Characteristics of Innovation to Explain Online Teaching Intention
}

\author{
Colleen Carraher-Wolverton and Zhiwei Zhu \\ BI Moody III College of Business Administration, University of Louisiana at Lafayette, USA \\ wolverton@louisiana.edu \\ zhiwei.zhu@louisiana.edu
}

\begin{abstract}
There exists an increasing demand for online education; however, faculty may question the value of online courses as they grapple with making a connection between the face-to-face classroom and the online learning experience. Much research has focused on factors relating to student engagement, although we posit that faculty engagement represents an important aspect in the online learning context that has been fairly overlooked in the engagement research stream. Therefore, understanding the factors that influence a faculty's intention to teach an OL course in addition to their level of engagement in teaching an online learning course is vital to the growth and success of an OL program. Therefore, in this study, we seek to not only understand the factors that influence faculty's intention to teach online learning courses but also an instructor's level of faculty engagement in online learning courses. We sought a novel lens with which to examine this phenomenon, so this study utilizes the perceived characteristics of innovation (PCI) to examine the relationships between faculty engagement and intention to teach online learning courses. We conducted a survey of 99 instructors from a large public university in order to assess the impact of $\mathrm{PCl}$ on faculty engagement and intention to teach online courses. Structural equation modeling (SEM) was employed to analyze the data, concluding that result demonstration, relative advantage, and compatibility influence a faculty's level of engagement in an online learning course, which in turn influences their intention to teach an OL course. We discuss how this research can be utilized in order to more effectively allocate scarce resources by focusing on the relative advantage of online learning, the measurability of online learning, and the way in which it can be compatible with instructors teaching preferences. We present this study to enable the beginning of a new stream of research into faculty engagement.
\end{abstract}

Keywords: online learning, faculty engagement, perceived characteristics of innovation ( $\mathrm{PCl}$ ), engagement, structural equation modeling, online education

\section{Introduction}

More than 770 million learners worldwide have been impacted by university and school closures (Zhong, 2020), and many of them are now engaged in online learning (OL). Even before the COVID-19 pandemic, online learning increasingly played an important role in higher education (Freeman and Urbaczewski, 2019) and was expected to grow to a $\$ 325$ billion market by 2025 (McCue, 2018); we posit that number will now increase. The rise of the Internet has created new ways of delivering courses to students including hybrid and online course delivery methods. There are more technology-related online courses than any other subject (The Chronicle of Higher Education, 2019). As information technology is rapidly evolving, students have become more interested in taking online courses while we are experiencing a digital revolution (Kaplan and Haenlein, 2016).

Students have begun to demand increased online course offerings for several reasons (Palvia et al., 2018, Wolverton, Hollier and Lanier, 2020). One of the reasons is that OL courses provide more flexible access to content, and instruction can be provided anytime and anywhere (Angiello, 2010, Coyner and McCann, 2004). Therefore, OL courses tend to be popular among students with jobs and families (Allen and Seaman, 2016, Lyons, 2004). For most of these students, an OL program represents their only path to a degree. Some OL students live in rural areas, do not have access to reliable transportation, face restricting disabilities, or find themselves with demanding family obligations ( $\mathrm{Li}$, Chen and $\mathrm{Wu}, 2020$ ). An OL education may represent the only method in which the student is able to obtain an education (Palvia et al., 2018). Therefore, over $70 \%$ of universities consider online learning as critical for long-term educational success (Carraher-Wolverton and Zhu, 2020) and a 'core business' of the university (Stone, 2017). 
Online education has been extensively researched during the last two decades. Many studies on online education have concentrated on students, focusing on topics such as the learners' decisions to accept online learning and their satisfaction with online learning (Ahmed, 2010). Although it is clear that students play role in online learning, we postulate that researchers have neglected the importance of faculty (Meyer and Murrell, 2014, Tanis, 2020, Tanner, Noser and Totaro, 2009). There exists a dearth of studies that examine faculty's role in online programs. As little is known about the faculty who will teach these online courses, we seek to fill this gap in the literature.

Many faculty have expressed skepticism and disinterest in online education (Carraher-Wolverton, 2021, Kebritchi, Lipschuetz and Santiague, 2017, Osika, Johnson and Buteau, 2009). Instructors often face lack of empowerment in development of their online course content, as they are encouraged to adopt predefined content (Kebritchi, Lipschuetz and Santiague, 2017). They also indicate that the responsibility that comes with the OL courses is more, or at least the same, as their counterpart face-to-face courses (Howell, Williams and Lindsay, Kebritchi, Lipschuetz and Santiague, 2017, Schwarz and Zhu, 2015). Furthermore, faculty cite an increase in communication challenges in online courses, as technology inhibits their ability to read non-verbal cues from students (Coppola, Hiltz and Rotter, 2002, Limperos et al., 2015).

As the demand for online course offering increases, teaching online has become an expectation of faulty members in recent years. When the COVID-19 pandemic occurred, essentially all instructors became online instructors overnight. However, Bolliger and Wasilik (2009) indicated that online instruction is a complex undertaking and requires a higher level of commitment from faculty. Many instructors, whether they have taught online courses or not, feel that they did not enjoy it as much as teaching face-to-face classes (Carraher Wolverton and Guidry Hollier, 2019).

Indeed, only $9 \%$ of instructors prefer to teach a $100 \%$ online course (Darby, 2019, Pomerantz and Brooks, 2017). Some instructors have attempted to teach online but struggled with learning new technology (Osika, Johnson and Buteau, 2009) or were never offered training on the online technology (Kebritchi, Lipschuetz and Santiague, 2017). Moreover, technology can become a distraction in the course when it fails or is unreliable (Chang, Shen and Liu, 2014, Crawley, Fewell and Sugar, 2009). Instructors often grapple with making the connection between the face-to-face classroom and the online learning experience (Carraher Wolverton and Tanner, 2019). Some instructors are concerned about student teaching evaluations, as they are not physically engaging with their students in the same way as a face-to-face classroom. Indeed, less than $30 \%$ of faculty members accept the value and legitimacy of online education (Allen and Seaman, 2016).

It is clear that there is a growing unmet demand for online education and on the other hand the level of faculty members' willingness to teach online is relatively low (Kebritchi, Lipschuetz and Santiague, 2017). Therefore, understanding the factors that influence a faculty's intention to teach an OL course in addition to their level of engagement in teaching an online learning course is vital to the growth and success of an OL program. Hence, the purpose of this study is to determine the factors that influence a faculty's level of engagement in teaching an OL course in addition to their intention to teach OL courses. As certain factors influence an individual's decision to adopt a particular innovation, we posit that online classes can represent an "education innovation".

\section{Literature Review}

\subsection{Perceived Characteristics of Innovating (PCl)}

Multiple theories are available to explain the diffusion or adoption of technological innovations. These theories include the Technology Acceptance Model (TAM) (Davis, 1989), the Unified Theory of Acceptance and Use of Technology (UTAUT) (Venkatesh et al., 2003), Diffusion of Innovation (DOI) (Rogers, 1983, Rogers, 2010), Process-based view of information technology (IT) acceptance (Schwarz et al., 2014), and Perceived Characteristics of Innovating (PCI) by Moore and Benbasat (1991). According to Rogers (1983), the rate of adoption is the relative speed with which an innovation is adopted by members of a social system. It is measured by the number of individuals who adopt a new idea in a specified period. The rate of adoption is a numerical indicant of the steepness of the adoption curve for an innovation. Rogers (1983) also demonstrates that the rate of adoption can be strongly dependent on a number of characteristics of an innovation itself such as relative advantage, compatibility, complexity, trialability, and observability. 
Studies in the online education research stream have applied well-accepted technology-acceptance models such as TAM (Liu et al., 2010, Ndubisi, 2006, Ndubisi and Chukwunonso, 2004) to predict intention of faculty to participate in online education. Similarly, we seek to apply a well-accepted technology-acceptance model to online education research. However, we are examining the phenomenon from the lens of the faculty, rather than the student, in order to determine the faculty's level of engagement and intention to participate in online education.

We selected the Perceived Characteristics of Innovating (PCI) as studies indicate that it explains substantially more variance than does TAM (Plouffe, Hulland and Vandenbosch, 2001, Poong and Eze, 2008) and it is more robust than TAM (Poong and Eze, 2008). Moore and Benbasat's (1991) PCI has been utilized to predict adoption of technology innovation in different industry settings. For example, Yaacob and Yusoff (2014) employed the PCI to examine the factors associated with the adoption perceived by trainer and trainees in computer-based training. They found that a positive relationship exists between PCI and adoption. Kim, Park and Lee (2017) utilized the perceived characteristics of innovation to investigate consumers' intention to use Buy-Online, Pickup in Store (BOPS). They found that relative advantage, complexity, compatibility, and risks involved in online shopping are important factors influencing consumers' intention to use BOPS. However, these relationships were significantly moderated by locational convenience and types of product. Hashem and Tann (2007) studied the impact of three groups of factors on the adoption of ISO 9000 standards by manufacturing companies. The three groups of factors are characteristics of innovation, characteristics of the external environment, and organizational characteristics. Their result demonstrates each of the three groups of factors are significantly related to the adoption of ISO 9000 .

The application of the Perceived Characteristics of Innovation can also be found in Chung and Holdsworth's (2012) study to investigate the relationship of the determinants of behavioral intent to adopt mobile commerce among the Y Generation. The researchers utilized structural equation modeling to test for construct validity and hypothesis testing. They concluded that Rogers' five perceived characteristics of innovation determined behavioral intent to adopt mobile commerce among the $\mathrm{Y}$ Generation. Thus, $\mathrm{PCI}$ has been applied in various contexts, and we seek to extend its application to examine the innovation of online learning.

In this study, we seek to apply the PCI to examine the adoption of the innovation of online learning. Specifically, we will employ PCl to determine the factors that influence a faculty's level of engagement in teaching an online learning course in addition to his/her intention to teach online learning courses. The issues surrounding a faculty's intention to teach online learning courses represents an important issue to address as the demand for online learning programs continues to increase (Freeman and Urbaczewski, 2019).

\subsection{Faculty engagement}

Engagement can be conceptualized by absorption, dedication, and vigor (Schaufeli, 2013, Schwarz and Zhu, 2015). Scholars have studied employee engagement (Saks, 2006, Schaufeli et al., 2002), student engagement (Kahu and Nelson, 2018, Schaufeli et al., 2002), and customer engagement (Prentice, Wang and Loureiro, 2019). Although most pedagogical research on engagement has focused on factors relating to student engagement (Schwarz and Zhu, 2015, Wolverton, 2018), we seek to extend the engagement research stream to address faculty engagement.

Understanding whether certain factors influence a faculty's level of engagement in a course and intention to teach an online course represents an important inquiry. We posit that the addition of the faculty engagement construct adds a related dimension whose importance has been clearly demonstrated on the student side and we postulate will be salient in the faculty decision as well. Therefore, we seek to not only understand the factors that influence faculty's intention to teach online learning courses but also an instructor's level of faculty engagement in OL courses.

\section{Methodology}

\subsection{Survey development}

We developed an online survey to collect data for our study, creating items for all the constructs to be studied. We adapted Moore and Benbasat's (1991) characterization of the Perceived Characteristics of Innovating (PCl) concepts to incorporate the OL context. Thus, we extend $\mathrm{PCl}$ from evaluating the adoption of technology to include evaluating an instructor's adoption of teaching an OL course. 
The items utilized to measure faculty engagement were adapted from Schaufeli et al.'s (2002) established multidimensional student engagement measure, including absorption, dedication, and vigor. The behavioral intention (BI) measure was adapted from Venkatesh and Davis (2000). The construct names and items for the constructs are summarized in Table 1.

Table 1: Construct measures

\begin{tabular}{|c|c|c|}
\hline Measures & Anchors & References \\
\hline $\begin{array}{l}\text { Faculty Engagement } \\
\text { Vigor (VI) } \\
\text { 1. When I get up in the morning, I feel like teaching my online course. } \\
\text { 2. When teaching my online course, I feel bursting with energy. } \\
\text { 3. When working on teaching my online course I always persevere, even } \\
\text { when things do not go well. } \\
\text { 4. I can continue for very long periods at a time when working on } \\
\text { teaching my online course. } \\
\text { 5. When working on teaching my online course, I am very resilient, } \\
\text { 6. Whentally. } \\
\text { Dedication (DE) } \\
\text { 1. To me, working on teaching my online course is challenging. } \\
\text { 2. Teaching my online course inspires me. } \\
\text { 3. I am enthusiastic about teaching my online course. } \\
\text { 4. I am proud of the work that I do to teach my online course. } \\
\text { 5. I find teaching my online course to be full of meaning and purpose. } \\
\text { Absorption (AB) } \\
\text { 1. When I am teaching my online course, I forget everything else around } \\
\text { 2. I get carried away when I am working on teaching my online course } \\
\text { 3. It is difficult to detach myself from working on teaching my online } \\
\text { 4. I get immersed in working on teaching my online course. } \\
\text { 5. I feel happy when I work intensely on teaching my online course. }\end{array}$ & $\begin{array}{l}\text { Strongly Agree- } \\
\text { Strongly Disagree }\end{array}$ & $\begin{array}{l}\text { Adapted from } \\
\text { Schaufeli et al } \\
2002\end{array}$ \\
\hline $\begin{array}{l}\text { Intention to teach an online course } \\
\text { 1. I intend to teach an online course in the future. } \\
\text { 2. I predict that I would teach an online course if I were asked. }\end{array}$ & $\begin{array}{l}\text { Strongly Agree- } \\
\text { Strongly Disagree }\end{array}$ & $\begin{array}{l}\text { Venkatesh and } \\
\text { Davis } 2000\end{array}$ \\
\hline $\begin{array}{l}\text { Perceived Characteristics of Innovating }(P C I) \\
\text { Voluntariness } \\
\text { 1. My Department Chair or Dean does not require me to teach online. } \\
\text { 2. Although it might be helpful, teaching online is certainly not } \\
\text { compulsory in my job. }\end{array}$ & $\begin{array}{l}\text { Strongly Agree- } \\
\text { Strongly Disagree }\end{array}$ & $\begin{array}{l}\text { Adapted from } \\
\text { Moore and } \\
\text { Benbasat } 1991\end{array}$ \\
\hline $\begin{array}{l}\text { Relative Advantage } \\
\text { 1. Compared to traditional (face-to-face) teaching, teaching online... } \\
\text { 2. takes less time } \\
\text { 3. provides a higher-quality teaching experience } \\
\text { 4. is easier } \\
\text { 5. makes me a more effective instructor } \\
6 . \quad \text { gives me greater control over my work }\end{array}$ & & \\
\hline $\begin{array}{l}\text { Compatibility } \\
\text { 1. Teaching online is compatible with the way I work. } \\
\text { 2. I think that teaching online fits well with the way I like to work. } \\
\text { 3. Teaching online fits into my work style. }\end{array}$ & & \\
\hline $\begin{array}{l}\text { Image } \\
\text { 1. People at my university who teach online have more prestige than } \\
\text { those who do not. } \\
\text { 2. People at my university who teach online have a high profile. } \\
\text { 3. Teaching online is a status symbol at my university. }\end{array}$ & & \\
\hline
\end{tabular}




\begin{tabular}{|l|l|}
\hline Measures & Anchors \\
\hline Ease of Use & References \\
1. I believe that it is easy to teach online. & \\
2. Becoming comfortable teaching online was/would be easy for me. & \\
Result Demonstrability & \\
1. I would have no difficulty telling others about the benefits of teaching & \\
online. & \\
2. I believe I could communicate to others the consequences of not & \\
3. The benefits of teaching online are apparent to me. & \\
4. I would have difficulty explaining why teaching online may or may not & \\
$\quad$ be beneficial. & \\
Visibility & \\
1. At my university, I am aware that many instructors are teaching online & \\
2. Teurses. & \\
Trialability & \\
1. Before deciding whether to teach online, I was familiar with what it & \\
2. I was provided with adequate training about how to teach online. &
\end{tabular}

\subsection{Data collection}

In order to test the proposed research model, an online survey was created to collect data for this study. We sent 821 invitations to instructors from seven different colleges, including instructors who currently teach online and those who do not teach online at a large public university in the southeastern United States. We received 99 usable responses for a response rate of $12 \%$. According to the "10 times" rule, the sample size should be at least 10 times the number of incoming paths to the construct with the greatest number of incoming paths (Barclay, Higgings and Thompson, 1995, Chin and Newsted, 1999, Hair et al., 2017). Therefore, the sample size is sufficient.

\subsection{Profile of respondents}

A greater percentage of the respondents were female (68.69\%). As displayed in Table 2, the greatest number of respondents came from the College of Liberal Arts (24.24\%), Business (23.23\%), and Education (19.19\%).

Table 2: Respondent's college

\begin{tabular}{|l|l|}
\hline College & Percentage \\
\hline Liberal Arts & $24.24 \%$ \\
\hline Business & $23.23 \%$ \\
\hline Education & $19.19 \%$ \\
\hline Nursing & $15.15 \%$ \\
\hline Sciences & $13.13 \%$ \\
\hline Arts & $3.03 \%$ \\
\hline Engineering & $2.02 \%$ \\
\hline
\end{tabular}

As displayed in Table 3, most of the respondents (78.79\%) designed and taught an online course.

Table 3: Experience of respondents

\begin{tabular}{|l|l|}
\hline Experience of Respondents & Percentage \\
\hline Taught an online course (only) & $10.10 \%$ \\
\hline Designed an online course (only) & $0.01 \%$ \\
\hline Designed and Taught an online course & $78.79 \%$ \\
\hline None of the Above & $11.11 \%$ \\
\hline
\end{tabular}




\subsection{Data analysis}

We analyzed the data using structural equation modeling (SEM). Given our small sample size ( $n=99)$ and the corresponding lack of statistical power in utilizing a covariance-based approach (Westland, 2010), we selected the partial least squares (PLS) approach, specifically Smart PLS 3.0 (Ringle, Wende and Becker, 2015) software. We selected to utilize PLS, because it is the recommended method when the sample size for the data is limited (Barclay, Higgings and Thompson, 1995, Chin, Marcolin and Newsted, 2003, Chin and Newsted, 1999, Gefen, Straub and Boudreau, 2000, Hair et al., 2017).

\subsection{Measurement model}

The first step in a PLS analysis is the analysis of the measurement (or outer) model. Following the procedures outlined by Wright et al. (2012), our first step was the creation of a first-order measurement model. We began by analyzing the loadings and cross-loadings of all items to ensure that they each loaded on their respective constructs (see Table 4). As some items exhibited a coefficient alpha below the .70 threshold (Nunnally, 1978), they were removed from further analysis. We were thus able to simplify the model while ensuring that the sampling domain had been adequately captured (Churchill, 1979) without including items that make progressively less of an impact on the reliability (Carmines and Zeller, 1979). We then reanalyzed the loadings and cross-loadings of the items, and all loadings were greater on the intended construct than on any other constructs. Consequently, upon determining that none of the remaining items loaded higher on any construct other than the intended construct, we retained all the items.

Table 4: Loadings and Cross Loadings

\begin{tabular}{|c|c|c|c|c|c|c|c|c|c|c|c|c|}
\hline \multicolumn{3}{|c|}{ Loadings and Cross Loadings } & \multirow[b]{2}{*}{$\begin{array}{l}\text { Ease } \\
\text { of } \\
\text { Use }\end{array}$} & \multirow[b]{2}{*}{ Image } & \multirow[b]{2}{*}{$\begin{array}{l}\text { Relative } \\
\text { Advanta } \\
\text { ge }\end{array}$} & \multirow[b]{2}{*}{$\begin{array}{l}\text { Result } \\
\text { Demonstrabil } \\
\text { ity }\end{array}$} & \multirow[b]{2}{*}{$\begin{array}{l}\text { Trialabilli } \\
\text { ty }\end{array}$} & \multirow[b]{2}{*}{$\begin{array}{l}\text { Visibili } \\
\text { ty }\end{array}$} & \multirow[b]{2}{*}{$\begin{array}{l}\text { Voluntarin } \\
\text { ess }\end{array}$} & \multirow[b]{2}{*}{$\begin{array}{l}\text { Absorpti } \\
\text { on }\end{array}$} & \multirow[b]{2}{*}{$\begin{array}{l}\text { Dedicati } \\
\text { on }\end{array}$} & \multirow[b]{2}{*}{ Vigor } \\
\hline & $\begin{array}{l}\text { Intentio } \\
\mathrm{n}\end{array}$ & $\begin{array}{l}\text { Compatibil } \\
\text { ity }\end{array}$ & & & & & & & & & & \\
\hline INTENT1 & 0.923 & 0.636 & 0.24 & $\begin{array}{l}-258 \\
0.258\end{array}$ & 0.306 & 0.255 & 0.099 & 0.03 & -0.168 & 0.487 & 0.514 & 0.526 \\
\hline INTENT2 & 0.908 & 0.555 & 0.351 & -2.242 & 0.368 & 0.234 & 0.141 & 0.005 & -0.141 & 0.406 & 0.479 & 0.521 \\
\hline PCI-COMP1 & 0.56 & 0.961 & 0.375 & 0.167 & 0.623 & 0.631 & 0.337 & -0.021 & -0.115 & 0.618 & 0.657 & 0.677 \\
\hline PCI-COMP2 & 0.644 & 0.957 & 0.384 & $\overline{0}-127$ & 0.633 & 0.621 & 0.327 & -0.018 & -0.164 & 0.614 & 0.74 & 0.699 \\
\hline PCI-COMP3 & 0.67 & 0.954 & 0.377 & $\overline{0.081}$ & 0.59 & 0.567 & 0.26 & 0.061 & -0.168 & 0.539 & 0.642 & 0.646 \\
\hline PCI-EOU3 & 0.32 & 0.396 & 1 & $\overline{-}-074$ & 0.317 & 0.419 & 0.285 & -0.098 & -0.045 & 0.248 & 0.338 & 0.355 \\
\hline PCI-IMG1 & -0.168 & -0.084 & -0.02 & 0.845 & 0.187 & 0.054 & 0.118 & 0.071 & -0.088 & -0.04 & -0.006 & 0.042 \\
\hline PCI-IMG2 & -0.189 & -0.08 & 0.041 & 0.922 & 0.208 & 0.088 & 0.174 & 0.209 & -0.069 & -0.099 & -0.07 & $\overline{0.041}$ \\
\hline PCI-IMG3 & -0.304 & -0.155 & $\overline{0.153}$ & 0.956 & 0.13 & -0.002 & 0.089 & 0.042 & -0.08 & -0.094 & -0.036 & $\overline{0}-066$ \\
\hline $\begin{array}{l}\text { PCI-RA2 } \\
\end{array}$ & 0.378 & 0.605 & 0.364 & 0.139 & 0.898 & 0.515 & 0.146 & -0.125 & -0.124 & 0.507 & 0.657 & 0.678 \\
\hline PCI-RA4 & 0.305 & 0.551 & 0.144 & 0.131 & 0.874 & 0.523 & 0.073 & -0.104 & -0.126 & 0.473 & 0.665 & 0.583 \\
\hline PCI-RA5 & 0.259 & 0.51 & 0.324 & 0.19 & 0.828 & 0.473 & 0.217 & -0.069 & -0.11 & 0.384 & 0.517 & 0.453 \\
\hline $\begin{array}{ll}\text { PCI-RD1 } \\
\end{array}$ & 0.228 & 0.531 & 0.339 & 0.032 & 0.517 & 0.908 & 0.178 & 0.062 & -0.031 & 0.527 & 0.56 & 0.549 \\
\hline PCI-RD3 & 0.26 & 0.624 & 0.424 & 0.039 & 0.545 & 0.918 & 0.234 & 0.043 & -0.198 & 0.555 & 0.634 & 0.522 \\
\hline PCI-TRIAL1 & 0.216 & 0.249 & 0.231 & -0.06 & 0.125 & 0.04 & 0.724 & 0.051 & -0.059 & 0.121 & 0.159 & 0.197 \\
\hline PCI-TRIAL2 & 0.023 & 0.267 & 0.228 & 0.23 & 0.133 & 0.287 & 0.863 & 0.061 & 0.154 & 0.164 & 0.156 & 0.248 \\
\hline PCI-VIS2 & 0.02 & 0.006 & $\overline{0.098}$ & 0.124 & -0.117 & 0.057 & 0.071 & 1 & -0.014 & -0.016 & -0.092 & $\overline{0.091}$ \\
\hline PCI-VOL1 & -0.15 & -0.143 & $\overline{-}-072$ & $\overline{-}-079$ & -0.106 & -0.141 & 0.032 & -0.025 & 0.952 & -0.203 & -0.167 & $\overline{0}-014$ \\
\hline PCI-VOL2 & -0.174 & -0.155 & $\overline{0}-022$ & $-\overline{0}-073$ & -0.155 & -0.11 & 0.111 & -0.005 & 0.972 & -0.248 & -0.207 & $\overline{0}-051$ \\
\hline $\begin{array}{l}\text { TEACH-ENG- } \\
\text { AB1 }\end{array}$ & 0.243 & 0.293 & 0.081 & 0.071 & 0.334 & 0.333 & 0.245 & 0.019 & -0.107 & 0.713 & 0.351 & 0.373 \\
\hline $\begin{array}{l}\text { TEACH-ENG- } \\
\text { AB2 }\end{array}$ & 0.338 & 0.468 & 0.056 & $\overline{0}-145$ & 0.304 & 0.489 & 0.166 & 0.046 & -0.336 & 0.845 & 0.54 & 0.402 \\
\hline $\begin{array}{l}\text { TEACH-ENG- } \\
\text { AB3 }\end{array}$ & 0.281 & 0.388 & 0.048 & $\begin{array}{l}-103 \\
0.103\end{array}$ & 0.27 & 0.304 & 0.194 & 0.027 & -0.206 & 0.757 & 0.357 & 0.329 \\
\hline $\begin{array}{l}\text { TEACH-ENG- } \\
\text { AB4 }\end{array}$ & 0.45 & 0.632 & 0.253 & $\overline{0}-145$ & 0.491 & 0.58 & 0.066 & -0.059 & -0.2 & 0.842 & 0.649 & 0.557 \\
\hline $\begin{array}{l}\text { TEACH-ENG- } \\
\text { AB5 }\end{array}$ & 0.52 & 0.542 & 0.428 & $\overline{0}-055$ & 0.586 & 0.522 & 0.091 & -0.064 & -0.08 & 0.732 & 0.688 & 0.587 \\
\hline $\begin{array}{l}\text { TEACH-ENG- } \\
\text { DE2 }\end{array}$ & 0.409 & 0.634 & 0.276 & 0.031 & 0.711 & 0.619 & 0.281 & -0.086 & -0.094 & 0.651 & 0.923 & 0.735 \\
\hline $\begin{array}{l}\text { TEACH-ENG- } \\
\text { DE3 }\end{array}$ & 0.53 & 0.645 & 0.312 & -0.057 & 0.617 & 0.594 & 0.115 & -0.163 & -0.212 & 0.628 & 0.911 & 0.77 \\
\hline $\begin{array}{l}\text { TEACH-ENG- } \\
\text { DE4 }\end{array}$ & 0.417 & 0.59 & 0.286 & 0.017 & 0.539 & 0.575 & 0.128 & 0.018 & -0.227 & 0.553 & 0.797 & 0.592 \\
\hline $\begin{array}{l}\text { TEACH-ENG- } \\
\text { DE5 }\end{array}$ & 0.556 & 0.638 & 0.316 & -0.09 & 0.64 & 0.522 & 0.16 & -0.08 & -0.17 & 0.601 & 0.887 & 0.672 \\
\hline $\begin{array}{l}\text { TEACH-ENG- } \\
\text { VI1 }\end{array}$ & 0.633 & 0.711 & 0.26 & $\overline{0}-116$ & 0.567 & 0.533 & 0.176 & -0.101 & -0.026 & 0.555 & 0.694 & 0.86 \\
\hline $\begin{array}{l}\text { TEACH-ENG- } \\
\text { VI2 }\end{array}$ & 0.428 & 0.611 & 0.339 & 0.015 & 0.65 & 0.541 & 0.404 & -0.052 & -0.019 & 0.566 & 0.743 & 0.911 \\
\hline $\begin{array}{l}\text { TEACH-ENG- } \\
\text { VI6 }\end{array}$ & 0.42 & 0.497 & 0.324 & 0.032 & 0.513 & 0.44 & 0.131 & -0.085 & -0.051 & 0.414 & 0.602 & 0.822 \\
\hline
\end{tabular}


We next evaluated the reliability, discriminant, and convergent validity of the first-order measurement model. Utilizing the item loadings, we calculated the internal composite reliability (ICR) to evaluate the measure's reliability, finding that all the dimensions exceeded the .70 threshold and were all above 0.78 (Table 5).

Table 5: Composite Reliability and Average Variance Extracted (AVE)

\begin{tabular}{|l|l|l|}
\hline & $\begin{array}{c}\text { Composite } \\
\text { Reliability }\end{array}$ & $\begin{array}{c}\text { Average } \\
\text { Variance } \\
\text { Extracted } \\
\text { (AVE) }\end{array}$ \\
\hline Absorption & 0.885 & 0.608 \\
\hline Compatibility & 0.971 & 0.917 \\
\hline Dedication & 0.933 & 0.776 \\
\hline Ease of Use & 1 & 1 \\
\hline Image & 0.934 & 0.826 \\
\hline Intention & 0.912 & 0.838 \\
\hline Relative Advantage & 0.901 & 0.752 \\
\hline Result Demonstrability & 0.909 & 0.834 \\
\hline Trialabillity & 0.775 & 0.634 \\
\hline Vigor & 0.899 & 0.748 \\
\hline Visibility & 1 & 1 \\
\hline Voluntariness & 0.962 & 0.926 \\
\hline
\end{tabular}

Moreover, to estimate convergent validity, we evaluated each dimension's average variance extracted (AVE). Utilizing the threshold value of 0.50 for AVE (Barclay, Higgings and Thompson, 1995), our findings support convergent validity (Barclay, Higgings and Thompson, 1995).

\section{Discussion}

Our results indicate that certain factors in the $\mathrm{PCl}$ model predict intention, while other factors do not exert significant influence. Specifically, compatibility $(\beta=0.343, t=3.271, p<0.01)$ measures whether an innovation is consistent with the set of norms, values and other cultural aspects or religious beliefs that predominate in the population. Result demonstrability $(\beta=0.284, t=3.459, \mathrm{p}<0.01)$ measures the degree to which the results of using an innovation are perceived to be tangible. Relative advantage $(\beta=0.335, t=3.480, p<0.01)$ indicates that an innovation will be adopted more widely when it is considered superior to the alternative solution that it replaces. All three above mentioned factors influence faculty engagement. However, image $(\beta=-0.104, t=1.136$, $n s)$, ease of use $(\beta=-0.006, t=0.092, n s)$, trialability $(\beta=0.038, t=0.658, n s)$, voluntariness $(\beta=-0.051, t=0.928$, $n s)$, and visibility ( $\beta=-0.014, t=0.202, n s)$ do not impact faculty engagement. Moreover, all three of the first order constructs were components of the second order construct of engagement: vigor $(\beta=0.875, t=30.959, p$ $<0.001)$; dedication $(\beta=0.922, t=76.439, p<0.001)$; and absorption $(\beta=0.858, t=30.374, p<0.001)$. Finally, faculty engagement influences intention to teach an $\mathrm{OL}$ course $(\beta=0.602, t=12.145, p<0.001)$. The results are displayed in the structural model in Figure 1. 


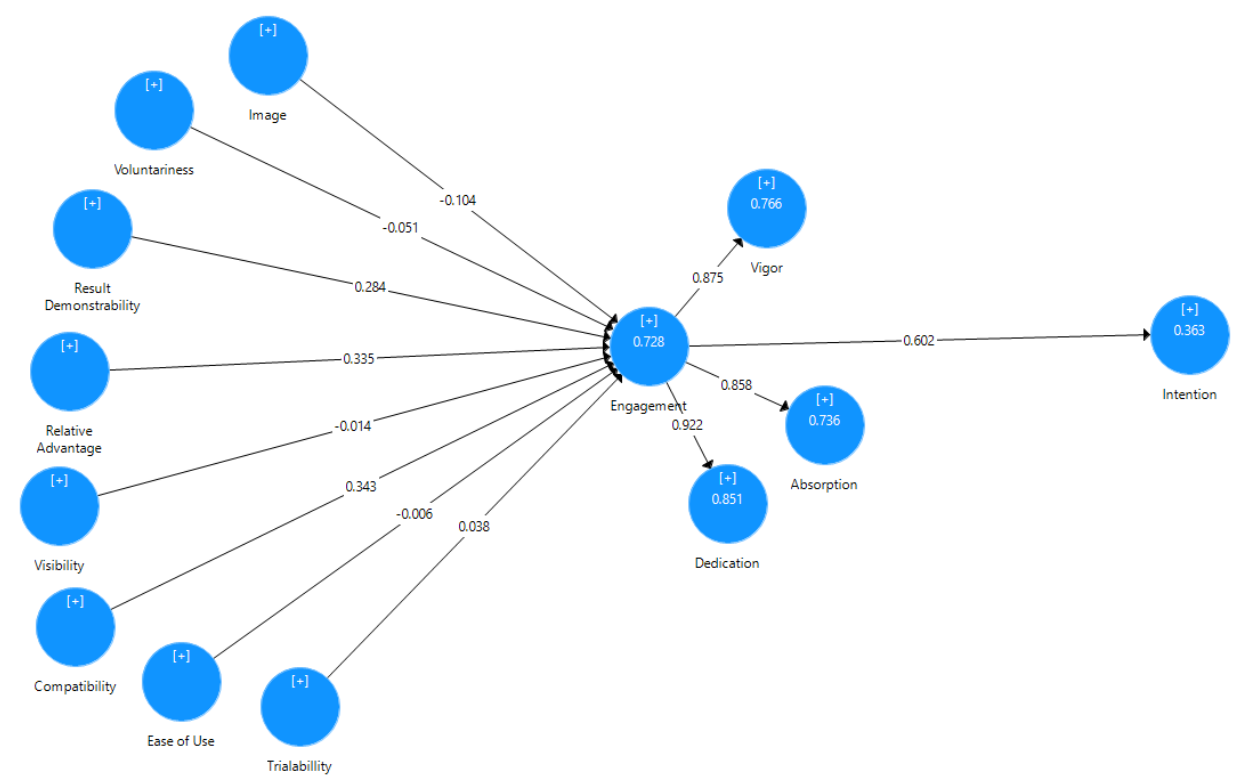

Figure 1: Research model

As the number of online learning courses offered at universities continues to increase, we propose that examining the factors that influence instructor's intention to teach an online course in addition to their engagement in teaching online courses represents an important contribution to the body of knowledge. Knowledge of the significant factors in addition to the unrelated factors enables universities to better target their efforts at motivating and engaging their faculty to teach OL courses. By demonstrating that certain factors do not influence a faculty's level of engagement or motivation, a university can instead focus on the factors with stronger influence.

Specifically, the findings indicate that result demonstrability, relative advantage, and compatibility influence a faculty's level of engagement in an online course, which in turn influences their intention to teach an OL course.

We will now discuss each of the $\mathrm{PCl}$ characteristics that influence faculty engagement and intention to teach an OL course.

\subsection{Relative Advantage}

Relative advantage describes the degree to which an instructor perceives teaching online as being better than teaching face-to-face. Thus, our findings demonstrate the importance of an instructor understanding the benefits of teaching online versus teaching face to face. By explaining the benefits to the faculty, instructors can begin to focus on some of the positive aspects of teaching OL courses. Moreover, explaining how OL courses are desired by students and can benefit some underserved students can assist in strengthening the perceived relative advantage of $\mathrm{OL}$ courses. For example, students who work full-time are often required to attend classes after a long day of work. With online courses, the students are able to time shift their coursework, listening to lectures and completing assignments on days when they are not already exhausted from a long workday.

\subsection{Compatibility}

Compatibility refers to the degree to which teaching online is perceived as being consistent with the existing values, needs, and past experiences of potential instructors. Just as students' schedules have become busier, instructor's time is often split between research, service, and personal activities. Therefore, the benefits that students are seeking from the flexibility of online learning courses can also be found for instructors. Instructors with heavy research, service, or personal responsibilities may value the flexibility that teaching online learning courses offers, as it may correspond with their existing needs and can therefore be compatible with their teaching preferences.

\subsection{Result demonstrability}

Result demonstrability is characterized as the extent to which teaching online is perceived as having measurable advantages that can be explained by the instructor. Result demonstrability involves the instructor being familiar 
with the benefits and struggles with online learning. This knowledge should include the ability to communicate both the benefits and difficulties with teaching online. Studies demonstrate the benefits of providing realistic portrayals (Buckley et al., 1998, Schwarz, 2011, Schwarz, 2015, Schwarz and Zhu, 2015, Wolverton et al., 2020). Thus, increasing knowledge of the realistic struggles of shifting their teaching paradigm to support online education, rather than merely marketing the benefits of online learning, can provide the instructor with greater confidence in their level of knowledge. This assurance can also provide the instructors with a greater ability to communicate about their experiences with teaching online. As faculty members tend to listen to their colleagues, this firsthand communication is vital.

\subsection{Non-significant factors}

Almost as important to consider as the significant factors are the characteristics that do not influence a faculty member's level of engagement in OL courses and their intention to teach online. These include image, voluntariness, visibility, ease of use, and trialability. Therefore, resources invested in increasing the pressure to teach online learning courses or increasing the status of teaching online courses will be ineffective. Furthermore, resources spent to ensure that it is easy to teach online courses or spending resources to provide exposure to online teaching will not influence an instructor's intention to teach online.

Resources are better spent focusing on the relative advantage of online learning, the measurability of online learning, and the way in which it can be compatible with instructors teaching preferences. By focusing on the factors that most strongly influence faculty engagement and intention to teach OL courses, resources can be more efficiently utilized to fulfill the need to offer more online courses. Specifically, we offer a couple of pointers to guide institutional practices:

1. Faculty need to be supported for their OL teaching (Van Wart et al., 2019). Research indicates that millennials, who represent the future of the faculty, seek employment at organizations where they feel valued (Carraher Wolverton, Credo and Matherne, 2021). Therefore, if faculty are needed to teach online courses and be engaged in their teaching, then they should be supported and engaged.

2. Faculty are more likely to devote time to OL practices if they see benefits or receive rewards or recognition for doing so (Van Wart et al., 2019). Due to their heavy workloads, it is very helpful to give the faculty time to experiment with OL teaching (Kumar et al., 2019).

3. Supportive networks can facilitate the diffusion of $\mathrm{OL}$ teaching. Training and workshops can encourage adoption of OL teaching (Mansbach and Austin, 2018). IT specialists and library representatives can be important in the OL course design. Students can play an important role in the evaluation of the resources (Khan et al., 2017).

\section{Limitations}

Although we found some interesting findings and useful results, our study was not without some areas for improvement. First, we utilized PLS for data analysis. Some researchers question the use of PLS for data analysis, claiming that it can allow for mis-specified measurement models based upon the fit indices that are typically reported (Gefen, 2019). However, others argue that PLS is a robust method (Sarstedt et al., 2020), and it has been extensively used in IS research (Kock and Hadaya, 2018).

Others might argue that our sample size was small, with 99 respondents. Therefore, we would encourage other researchers to replicate our study. However, according to the "10 times" rule (Barclay, Higgings and Thompson, 1995, Chin and Newsted, 1999, Hair et al., 2017), the sample size is sufficient to run our model.

\section{Opportunities for future research}

The researchers postulate that this study enables the beginning of a new stream of research into faculty engagement. The research stream of student engagement is healthy and diverse, yet there is a paucity of studies from the faculty lens. We postulate that if we can understand how to engage our best faculty in online education, then the students will be more engaged. At this point, however, there is no scientific way of knowing this, because it has never been studied; and, until now, we have never had a faculty engagement construct available to conduct these studies. Therefore, we encourage researchers to study the impact of faculty engagement on phenomenon such as student engagement, faculty burnout, and student learning. 
With the collection of additional data, other relationships could be examined. For example, by surveying individuals who teach online and those who do not teach online, a researcher could investigate whether differences exist between continuance intentions and intentions to adopt.

\section{Conclusions}

As the number of $\mathrm{OL}$ courses increase, we must ensure that we have the faculty necessary to teach these courses. Therefore, in this study, the researchers seek to understand how to encourage and motivate more instructors to be involved in online teaching. Specifically, we have extended the perceived characteristics of innovation ( $\mathrm{PCl}$ ) model to examine its influence on faculty engagement and intention to teach online learning courses.

Although student engagement has been rather extensively studied, scant research has investigated the importance of faculty engagement in improving student learning. Through this study, we provide items to measure faculty engagement, which are adapted from an established student engagement measure (Schaufeli et al., 2002). Therefore, this represents a contribution to the engagement literature. We also contribute to the online learning literature by examining the influence of the $\mathrm{PCl}$ characteristics on faculty engagement and intention to teach $\mathrm{OL}$ courses.

The findings from this study can be utilized to understand the characteristics that engage faculty in OL courses and spur them on to teach OL courses. As demand for OL courses continues to increase, universities will need engaged faculty to provide high-quality education to students from all areas. This study seeks to enhance this effort, as we continue to move into the digital revolution.

\section{References}

Ahmed, H.M.S., 2010. Hybrid e-learning acceptance model: Learner perceptions. Decision Sciences Journal of Innovative Education, 8(2), pp.313-346.

Allen, I.E. and Seaman, J., 2016. Online report card: tracking online education in the United States. Babson Park, MA: Babson Survey Research Group. Babson College.

Angiello, R., 2010. Study looks at online learning vs. Traditional Instruction. Education Digest: Essential Readings Condensed for Quick Review, 76(2), pp.56-59.

Barclay, D., Higgings, C. and Thompson, R., 1995. The partial least squares (PLS) approach to casual modeling: personal computer adoption and use as an illustration. Technology Studies, 2, pp.285-309.

Bolliger, D.U. and Wasilik, O., 2009. Factors influencing faculty satisfaction with online teaching and learning in higher education. Distance Education, 30(1), pp.103-116.

Buckley, M.R., Fedor, D.B., Veres, J.G., Wiese, D.S. and Carraher, S.M., 1998. Investigating newcomer expectations and jobrelated outcomes. Journal of Applied Psychology, 83(3), pp.452-461.

Carmines, E.G. and Zeller, R.A., 1979. Reliability and validity assessment. Thousand Oaks, CA: Sage Publications.

Carraher-Wolverton, C., 2021. Engaging faculty to facilitate student engagement in online courses: Southeast Decision Sciences Institute Conference (Virtual), February 11, 2021. https://sedsi2021.exordo.com.

Carraher-Wolverton, C. and Zhu, Z., 2020. The importance of faculty engagement in online courses. Southeast Decision Sciences Institute's 50th Annual Meeting. Charleston, SC, Decision Sciences Institute.

Carraher Wolverton, C., Credo, K. and Matherne, C., 2021. Development of an organizational coolness concept from an examination of millennial perceptions of cool and uncool employer organizations. Journal of Organizational Change Management, 34(3), pp.672-687.

Carraher Wolverton, C. and Guidry Hollier, B.N., 2019. A minimalist design for distance learning. International Journal of Educational Management, 33(7), pp.1457-1465.

Carraher Wolverton, C. and Tanner, J., 2019. Teaching public speaking to business students in the digital age: Updating our methods. International Journal of Education and Development using Information and Communication Technology, 15(3), pp.22-33.

Chang, C., Shen, H.-Y. and Liu, E.Z.-F., 2014. University faculty's perspectives on the roles of e-instructors and their online instruction practice. International Review of Research in Open and Distributed Learning, 15(3), pp.72-92.

Chin, W.W., Marcolin, B.L. and Newsted, P.R., 2003. A partial least squares latent variable modeling approach for measuring interaction effects: results from a monte carlo simulation study and an electronic-mail emotion/adoption study. Information Systems Research, 14(2), pp.189-217.

Chin, W.W. and Newsted, P.R., 1999. Structural equation modeling analysis with small samples using partial least squares. In: R. H. Hoyle, ed. Statistical strategies for small sample research. Thousand Oaks, CA, SAGE Publications, Inc. pp.307-341.

Chung, K.C. and Holdsworth, D.K., 2012. Culture and behavioural intent to adopt mobile commerce among the $Y$ Generation: comparative analyses between Kazakhstan, Morocco and Singapore. Young Consumers, 13(3), pp.224241. 
Churchill, G.A., Jr., 1979. A paradigm for developing better measures of marketing constructs. Journal of Marketing Research, 16(1), pp.64-73.

Coppola, N.W., Hiltz, S.R. and Rotter, N.G., 2002. Becoming a virtual professor: pedagogical roles and asynchronous learning networks. Journal of Management Information Systems, 18(4), pp.169-189.

Coyner, S.C. and McCann, P.L., 2004. Advantages and challenges of teaching in an electronic environment: The accommodate model. International Journal of Instructional Media, 31(3), pp.223-229.

Crawley, F.E., Fewell, M.D. and Sugar, W.A., 2009. Researcher and researched: the phenomenology of change from face-toface to online instruction. Quarterly Review of Distance Education, 10(2), pp.165-176.

Darby, F., 2019. How to be a better online teacher. [online]: The Chronicle of Higher Education. Available at: https://www.chronicle.com/article/how-to-be-a-better-online-teacher/ [Accessed July 10, 2021].

Davis, F.D., 1989. Perceived usefulness, perceived ease of use, and user acceptance of information technology. MIS Quarterly, 13(3), pp.319-340.

Freeman, L. and Urbaczewski, A., 2019. Critical success factors for online education: Longitudinal results on program satisfaction. Communications of the Association for Information Systems, 44(1), pp.30.

Gefen, D., 2019. A post-positivist answering back.: part 2: a demo in $r$ of the importance of enabling replication in PLS and LISREL. SIGMIS Database, 50(3), pp.12-37.

Gefen, D., Straub, D. and Boudreau, M.-C., 2000. Structural equation modeling and regression: Guidelines for research practice. Communications of the Association for Information Systems, 4(1), pp.7.

Hair, J.F., Jr., Hult, G.T.M., Ringle, C. and Sarstedt, M., 2017. A primer on partial least squares structural equation modeling (PLS-SEM). 2nd ed. Thousand Oaks, CA: SAGE Publications, Inc.

Hashem, G. and Tann, J., 2007. The adoption of ISO 9000 standards within the egyptian context: a diffusion of innovation approach. Total Quality Management \& Business Excellence, 18(6), pp.631-652.

Howell, S.L., Williams, P.B. and Lindsay, N.K., Thirty-two trends affecting distance education: an informed foundation for strategic planning. Online Journal of Distance Learning Administration, 6(3), pp.1-18.

Kahu, E.R. and Nelson, K., 2018. Student engagement in the educational interface: understanding the mechanisms of student success. Higher Education Research \& Development, 37(1), pp.58-71.

Kaplan, A.M. and Haenlein, M., 2016. Higher education and the digital revolution: About MOOCs, SPOCs, social media, and the Cookie Monster. Business Horizons, 59(4), pp.441-450.

Kebritchi, M., Lipschuetz, A. and Santiague, L., 2017. Issues and challenges for teaching successful online courses in higher education:A literature review. Journal of Educational Technology Systems, 46(1), pp.4-29.

Khan, A., Egbue, O., Palkie, B. and Madden, J., 2017. Active learning: Engaging students to maximize learning in an online course. Electronic Journal of e-Learning, 15(2), pp.107-115.

Kim, E., Park, M.-C. and Lee, J., 2017. Determinants of the intention to use Buy-Online, Pickup In-Store (BOPS): The moderating effects of situational factors and product type. Telematics and Informatics, 34(8), pp.1721-1735.

Kock, N. and Hadaya, P., 2018. Minimum sample size estimation in PLS-SEM: The inverse square root and gammaexponential methods. Information Systems Journal, 28(1), pp.227-261.

Kumar, S., Martin, F., Budhrani, K. and Ritzhaupt, A., 2019. Award-winning faculty online teaching practices: Elements of award-winning courses. Online Learning, 23(4), pp.160-180.

$\mathrm{Li}, \mathrm{R}$. , Chen, K. and Wu, D., 2020. Challenges and opportunities for coping with the smart divide in rural America. Annals of the American Association of Geographers, 110(2), pp.559-570.

Limperos, A.M., Buckner, M.M., Kaufmann, R. and Frisby, B.N., 2015. Online teaching and technological affordances: an experimental investigation into the impact of modality and clarity on perceived and actual learning. Computers \& Education, 83, pp.1-9.

Liu, I.F., Chen, M.C., Sun, Y.S., Wible, D. and Kuo, C.-H., 2010. Extending the TAM model to explore the factors that affect intention to use an online learning community. Computers \& Education, 54(2), pp.600-610.

Lyons, J.F., 2004. Teaching U.S. History online: Problems and prospects. The History Teacher, 37(4), pp.447-456.

Mansbach, J. and Austin, A.E., 2018. Nuanced perspectives about online teaching: mid-career and senior faculty voices reflecting on academic work in the digital age. Innovative Higher Education, 43(4), pp.257-272.

McCue, T., 2018. E-learning climbing to \$325 billion by 2025; UF Canvas Absorb Schoology Moodle. [online]: Forbes. Available at: https://www.forbes.com/sites/tjmccue/2018/07/31/e-learning-climbing-to-325-billion-by-2025-ufcanvas-absorb-schoology-moodle/?sh=3cb23ea93b39 [Accessed July 9, 2021].

Meyer, K.A. and Murrell, V.S., 2014. A national study of theories and their importance for faculty development for online teaching. Online Journal of Distance Learning Administration, 17(2), pp.1-15.

Moore, G.C. and Benbasat, I., 1991. Development of an instrument to measure the perceptions of adopting an information technology innovation. Information Systems Research, 2(3), pp.192-222.

Ndubisi, N., 2006. Factors of online learning adoption: A comparative juxtaposition of the theory of planned behaviour and the technology acceptance model. International Journal on E-Learning, 5(4), pp.571-591.

Ndubisi, N.O. and Chukwunonso, N.C., 2004. On-line learning adoption intention: comparing the predictive power of two competing models. Proceedings of HERDSA Conference, Miri, Sarawak, Malaysia, HERDSA.

Nunnally, J.C., 1978. An overview of psychological measurement. In: B. B. Wolman, ed. Clinical diagnosis of mental disorders. Springer. pp.97-146.

Osika, E.R., Johnson, R.Y. and Buteau, R., 2009. Factors influencing faculty use of technology in online instruction: a case study. Online Journal of Distance Learning Administration, 12(1), pp.1-14. 
Palvia, S., Aeron, P., Gupta, P., Mahapatra, D., Parida, R., Rosner, R. and Sindhi, S., 2018. Online education: Worldwide status, challenges, trends, and implications. Journal of Global Information Technology Management, 21(4), pp.233241.

Plouffe, C.R., Hulland, J.S. and Vandenbosch, M., 2001. Research report: Richness versus parsimony in modeling technology adoption decisions-understanding merchant adoption of a smart card-based payment system. Information Systems Research, 12(2), pp.208-222.

Pomerantz, J. and Brooks, D.C., 2017. ECAR study of faculty and information technology, 2017 [online]: EDUCAUSE. Available at: https://library.educause.edu/resources/2017/10/ecar-study-of-faculty-and-information-technology2017 [Accessed July 9, 2021].

Poong, Y.-S. and Eze, U.C., 2008. TAM vs. PCl: An analysis on the theoretical model parsimony and robustness across cultures. Communications of the IBIMA, 1(23), pp.198-201.

Prentice, C., Wang, X. and Loureiro, S.M.C., 2019. The influence of brand experience and service quality on customer engagement. Journal of Retailing and Consumer Services, 50, pp.50-59.

Ringle, C.M., Wende, S. and Becker, J.-M., 2015. SmartPLS 3. [online] Bönningstedt. Available at: http://www.smartpls.com [Accessed July 8, 2021].

Rogers, E.M., 1983. Diffusion of innovations. 3rd ed. New York, NY: The Free Press.

Rogers, E.M., 2010. Diffusion of innovations. New York: Simon and Schuster.

Saks, A.M., 2006. Antecedents and consequences of employee engagement. Journal of Managerial Psychology, 21(7), pp.600-619.

Sarstedt, M., Ringle, C.M., Cheah, J.-H., Ting, H., Moisescu, O.I. and Radomir, L., 2020. Structural model robustness checks in PLS-SEM. Tourism Economics, 26(4), pp.531-554.

Schaufeli, W.B., 2013. What is engagement. In: C. Truss et al., eds. Employee engagement in theory and practice London, Routledge. pp.15-35.

Schaufeli, W.B., Salanova, M., González-Romá, V. and Bakker, A.B., 2002. The measurement of engagement and burnout: a two sample confirmatory factor analytic approach. Journal of Happiness Studies, 3(1), pp.71-92.

Schwarz, A., Chin, W.W., Hirschheim, R. and Schwarz, C., 2014. Toward a process-based view of information technology acceptance. Journal of Information Technology, 29(1), pp.73-96.

Schwarz, C., 2011. Understanding the role of expectation disconfirmation theory on IT outsourcing success. PhD. Louisiana State University.

Schwarz, C., 2015. A review of management history from 2010-2014 utilizing a thematic analysis approach. Journal of Management History, 21(4), pp.494-504.

Schwarz, C. and Zhu, Z., 2015. The impact of student expectations in using instructional tools on student engagement: a look through the expectation disconfirmation theory lens. Journal of Information Systems Education, 26(1), pp.47-58.

Stone, C., 2017. Opportunity through online learning: Improving student access, participation and success in higher education. Perth: (NCSEHE). Curtin University.

Tanis, C.J., 2020. The seven principles of online learning: Feedback from faculty and alumni on its importance for teaching and learning. Research in Learning Technology, 28, pp.1-25.

Tanner, J.R., Noser, T.C. and Totaro, M.W., 2009. Business faculty and undergraduate students' perceptions of online learning: A comparative study. Journal of Information Systems Education, 20(1), pp.29-40.

The Chronicle of Higher Education, 2019. MOOC course distribution by subject, 2011-18. [online]: The Chronicle of Higher Education. Available at: https://www.chronicle.com/article/mooc-course-distribution-by-subject-2011-18-246684/ [Accessed July 11, 2020].

Van Wart, M., Ni, A., Rose, L., McWeeney, T. and Worrell, R., 2019. A literature review and model of online teaching effectiveness integrating concerns for learning achievement, student satisfaction, faculty satisfaction, and institutional results. Journal of Business Research, 10(1), pp.1-22.

Venkatesh, V. and Davis, F.D., 2000. A theoretical extension of the technology acceptance model: four longitudinal field studies. Management Science, 46(2), pp.186-204.

Venkatesh, V., Morris, M., Davis, F. and Davis, G., 2003. Unified theory of acceptance and use of technology (UTAUT). Management Information Systems Quarterly, 27, pp.425-478.

Westland, J.C., 2010. Lower bounds on sample size in structural equation modeling. Electronic Commerce Research and Applications, 9(6), pp.476-487.

Wolverton, C.C., 2018. Utilizing synchronous discussions to create an engaged classroom in online executive education. The International Journal of Management Education, 16(2), pp.239-244.

Wolverton, C.C., Hirschheim, R., Black, W.C. and Burleson, J., 2020. Outsourcing success in the eye of the beholder: examining the impact of expectation confirmation theory on IT outsourcing. Information \& Management, 57(6), pp.103236.

Wolverton, C.C., Hollier, B.N.G. and Lanier, P.A., 2020. The impact of computer self efficacy on student engagement and group satisfaction in online business courses. Electronic Journal of e-Learning, 18(2), pp.175-188.

Wright, R.T., Campbell, D.E., Thatcher, J.B. and Roberts, N., 2012. Operationalizing multidimensional constructs in structural equation modeling: Recommendations for IS research. Communications of the Association for Information Systems, 30(1), pp.368-412. 
Yaacob, H.F. and Zarir bin Yusoff, M., 2014. Comparing the relationship between perceived characteristics of innovation $(\mathrm{PCl})$ and adoption of computer based training among trainer and trainees. Procedia-Social and Behavioral Sciences, 155, pp.69-74.

Zhong, R., 2020. The Coronavirus exposes education's digital divide. [online]: The New York Times. Available at: https://www.nytimes.com/2020/03/17/technology/china-schools-coronavirus.html [Accessed July 9, 2021]. 